\title{
Recurring Topics in English Language Teachers' Written Teaching Philosophy Statements
}

\section{Caroline Payant E Eliana Hirano}

The present study analyzed in-service English as an additional language (EAL) teachers' written teaching philosophy (TP) statements in order to identify the dominant topics that comprise this supporting genre, as well as the use of personal pronouns and possessive adjectives. The sample included 27 in-service EAL teachers' TPs who were currently teaching, primarily, in the context of higher education and intensive English programs in North American settings. Each sentence was coded for a dominant topic, leading to the creation of 24 categories. To capture the unique characteristics of this genre, we created three success groups (i.e., Most successful, Successful, and Least successful) and compared their contents. Moreover, the first and last five topics for each TP for the three groups were compared, thus, establishing a pattern of opening and closing topics. Finally, we drew on corpus tools to uncover the manipulation of specific lexical features of this genre: the use of personal pronouns and possessive adjectives. The most prominent topics across the three groups included Teaching beliefs, Learning beliefs, Beliefs about learners, and Teacher growth. Differences were identified between the three groups in terms of both topics and organization.

La présente étude a analysé des énoncés écrits de professeurs d'anglais langue additionnelle (ALA) en poste décrivant leur philosophie pédagogique (PP) en vue d'identifier les thèmes dominants qui composent ce genre complémentaire ainsi que l'utilisation de pronoms personnels et d'adjectifs possessifs. L'échantillon portait sur la philosophie pédagogique de 27 professeurs d'ALA en poste présentement actifs, et ce, principalement dans le contexte de l'enseignement supérieur et des programmes d'anglais intensif dans des milieux nord-américains. Chaque phrase a été codifiée en fonction de son thème dominant, ce qui a amené la création de 24 catégories. Afin de saisir les caractéristiques particulières de ce genre, nous avons créé trois catégories de succès (c.-à-d. Succès supérieur, Succès, et Succès inférieur) et en avons comparé les contenus. De plus, les premiers et cinq derniers thèmes des trois groupes portant sur chaque PP ont été comparés, ce qui a permis d'établir un schéma de thèmes d'ouverture et de fermeture. Enfin, nous avons recouru à des outils de corpus textuel pour découvrir la manipulation des caractéristiques linguistiques particulières de ce genre : l'utilisation de pronoms personnels et d'adjectifs possessifs. Les thèmes les plus importants dans les trois groupes étaient les Croyances sur l'enseignement, les Croyances sur l'apprentissage, les Croyances sur les apprenants, et le Perfectionnement professionnel des professeurs. Des différences ont été identifiées 
entre les trois groupes tant au niveau des thèmes qu'à celui de l'organisation.

KEYWORDS: teaching philosophy, professional genre, supporting genre, L2 teacher training, EAL teachers

In education, teachers are often prompted to provide a written statement that represents the what and the how that informs their pedagogical choices. This statement, often referred to as a teaching philosophy (TP) statement, asks that educators articulate and exemplify their personal and professional beliefs about teaching and learning. The ability to ground pedagogical approaches in sound principles also guides second language (L2) educators' practices of Teaching English as a Second Language (TESL). While there is a formative function for such a statement such as promoting critical reflection on beliefs that guide teaching practices to foster personal and professional development, in actuality, within the North American context, the TP often serves summative purposes. In the context of general education, for instance, pre-service teachers (PST) often create a teaching portfolio submitted for assessment that includes a TP along with other documentation to demonstrate teaching beliefs and their relationship to practice (Adams-Bullock \& Hawk, 2010). However, the TP is also commonly included in application packets for employment purposes for academic positions and EAL teaching positions.

To date, a number of researchers has examined the contents of TPs in higher education to identify important topics (e.g., Kaplan, Meizlish, O'Neal, \& Wright, 2008; Schönwetter, Sokal, Friesen, \& Taylor, 2002); however, within the field of TESL, there is a paucity of research exploring the TP. Without clear, specific guidelines, L2 PSTs may use TPs available on the Internet as models, although PSTs may not have enough experience to determine if these are appropriate or meet their evaluators' expectations. Furthermore, L2 teacher educators may rely on guidelines that do not directly address language pedagogy when teaching and assessing TPs written by PSTs. The same faculty members, serving on search committees, may also base their evaluations of applicants' TPs based on their beliefs and professional practices of writing and reading TPs. While L2 teacher educators are certainly aware of research that informs their practice, we believe that more transparency would benefit writers' and evaluators' current practices. Given the gatekeeping function this statement can exercise in our increasingly competitive job market, it seems rather important that teacher educators, in-service teachers, and pre-service teachers better understand the TP. A necessary first step is to look closely at the topics that comprise the TP and identify its organization as well as its key linguistic features. The present study, thus, examined experienced in-service English as an additional language (EAL) teachers' $\mathrm{TP}$ statements to expand our understanding of TPs. 


\section{Rationale for writing a teaching philosophy}

In TESL programs, PSTs participate in content-based courses to broaden their knowledge base and often participate in language classrooms with experienced teachers to gain authentic teaching experiences. Through these experiences, EAL PSTs gain an extensive and complex amount of knowledge (Freeman \& Johnson, 1998; Johnston \& Goettsch, 2000; Lee, Murphy, \& Baker, 2015; Schulman, 1987; Vélez-Rendón, 2002; Wright, 2010). In addition, the imperative of engaging in reflective activities to facilitate the development of this extensive knowledge base is undisputed today. One type of reflective task that is often required of pre-service teachers in TESL programs is the drafting of a TP (Crookes, 2003). By engaging in the process of reflecting on and writing about the values underlying why one teaches, how one teaches, and what one teaches, future language educators are better positioned to critically examine and reevaluate their pedagogical approaches. However, the reflective function is certainly not the only motivation to write a TP. Pre-service and in-service teachers are increasingly required to document their practices and beliefs to secure employment. This is often done by way of teaching portfolios, which include an array of artefacts, such as lesson plans, student work, videos of teaching practices, and TPs (Adams-Bullock \& Hawk, 2010). For pre-service teachers, the portfolio can be used to assess the knowledge gained during their teacher preparation program and may differ from the TP written for securing employment.

To date, discussions and research that explore TPs tend to be geared toward candidates searching for academic positions in higher education contexts (Coppola, 2002; Korn, 2012; O'Neal, Meizlish, \& Kaplan, 2007). In higher education, a written TP is a component of applications for most jobs and, at later stages, for promotions or awards (Sankey \& Foster, 2012). Numerous scholars have discussed the importance, benefits, and challenges of this particular statement in this specific context (e.g., Boye, 2012; Chism, 199798; Goodyear \& Allchin, 1998; Kearns \& Subiño Sullivan, 2011; Korn, 2012; O'Neal, Meizlish, \& Kaplan, 2007). In the field of TESL, in contrast, the TP has received significantly less attention from researchers. Nevertheless, there is strong evidence that writing a TP is a common practice. A search on the Internet of the keywords "English as a second language teachers and teaching philosophy" generates more than 800,000 hits. Despite this, empirical studies reporting on TP for ESL teachers are limited. Given the limited number of studies from TESL, the remainder of the review, thus, focuses on publications that acknowledge the currency of this document for procuring a job and/ or academic advancement in the context of academic positions. Drawing on these publications will serve to situate the present study. 
Contents of teaching philosophy statements across the disciplines The necessity for producing a written TP statement transcends any given field of study within higher education, especially for full-time academic positions (see, for example, Avraamidou, 2015; Donnelly, 2009; Sheffield, 2013; Sankey \& Foster, 2012). Novice writers are often unsure about how to write one and tend to follow guidelines, conceptual models, or use models in the process of drafting their TP (Boyes, 2012; Goodyear \& Allchin, 1998; Kearns \& Subiño Sullivan, 2011; Korn, 2012). Schönwetter et al. (2002) conducted a survey of the existing literature to create a conceptual model that would inform the contents and structure of TP statements. They subsequently used this model in workshops where they gathered additional input from various stakeholders. Based on their analyses, they suggested that the specific topics of a TP include the definitions of teaching and of learning, a view of the learner and their development, a presentation of goals and expectations of the student-teacher relationship, and a discussion of teaching methodologies and evaluation. They maintain that a strong TP will ground the discussion within "an extensive knowledge of the literature" (p. 92). They further inform writers that this discussion should be supported with examples of their practices. More recently, also drawing on previously published works, Boye (2012) created a document to guide novice writers, in which she emphasized the need to include the following key topics: conceptualization of teaching and learning, goals for students, examples of how beliefs are enacted, assessment practices, and, finally, steps taken to ensure an inclusive learning environment. In addition to recommendations of content, she also provided guidance on organization and formatting as well as links to additional resources (i.e., guidelines from other Teaching and Learning Centers, rubrics, and empirical studies).

Recently, Swales and Feak (2011) published a book-long discussion on supporting genres to help novice writers navigate the various stages of their professional career (e.g., statements of purpose, formal communications with faculty, grant applications). Genre is a term for "grouping texts together, representing how writers typically use language to respond to recurring situations" (Hyland, 2004, p. 4). In discussing specific documents for the job market, they introduce the genres of curriculum vitae $(\mathrm{CV})$, job applications, and TPs. They suggest that TPs should include thoughts about (a) how students learn, (b) how instruction can best help student learning, (c) how your teaching might further improve, (d) how your students and instructors might be evaluated, (e) goals for students, and (f) beliefs about educational needs in today's world.

A few researchers have also conducted empirical investigations concerning TPs. For instance, Meizlish and Kaplan (2008) surveyed 457 search committee chairs in order to identify how they evaluated TPs and reported desirable characteristics of successful TPs. Specifically, this group of educa- 
tors maintained that successful TPs provide the reader with evidence of practice and of student-centered teaching. When applying for research-focused positions, a successful candidate should also demonstrate their enthusiasm and commitment for teaching and future growth. This research led to a subsequent publication (Kaplan, Meizlish, O'Neil, \& Wright, 2008) in which they present a rubric consisting of five categories: (a) goals for student learning, (b) enactment of goals, (c) assessment of goals, (d) creating an inclusive learning environment, and (e) structure, rhetoric, and language. They further highlight the importance of providing specific examples of how these ideas are actually enacted in practice. They note that this dimension is often absent in novice writers' TPs. Recently, Sankey and Foster (2012) turned to TPs written by faculty members who were recipients of awards for teaching excellence. They conducted a content-analysis of 86 TPs, which led to the identification of 11 themes. The dominant themes were student centredness, opportunity for students to learn, instructional variability, and expertise in subject matter. The least common themes were those relating to the creation of a conducive learning environment, teaching efficacy (organization and clarity), and technology. Their sample, provided primarily from faculty members at the rank of professor, reflects the work by exemplary faculty members who were very advanced in their careers.

Turning to the field of TESL, Payant (2017) examined in-service EAL teachers' self-reported TP writing practices and the perceived benefits of writing this document by means of a questionnaire. There was strong agreement among participants regarding the inclusion of beliefs about language learning, of language teaching, of teaching approaches, and of teacher roles. A subset reported the importance of identifying specific language learning theories and of providing examples of teaching activities/assessment. Overall, the participants valued the use of this genre for employment-related functions and reported having written or revised a TP for job searches. That study was the first to turn toward teachers of EAL, and it focused solely on those teachers' self-reported experiences of writing a TP. Based on those findings, we were unable to determine the actual topics that comprised their TPs and how they were organized.

Given the widespread presence of this supporting genre in education and its increasing presence in TESL, as evidenced by online TPs, it is important that we continue expanding our current understanding of TPs to provide guidance for novice writers. It is particularly important that we study the topics included in TPs written specifically in the TESL context in order to compare and contrast these with TPs written in other academic contexts to help future teachers prepare an application for an EAL teaching position. Before turning to the present study, based on the fact that TPs are personal testimonies, we provide a brief overview of research that explored ways to organize a TP and how personal identities can be enacted in TPs through the use of linguistic markers. 


\section{Guidance on the Process of Drafting TPs: Organization and Linguistic Markers}

In addition to paying close attention to the contents of TPs, previous research has looked at the organization and linguistic markers used in this genre, which has subsequently led to the creation of guidelines and/or models. These resources are often made available in Teaching and Learning centers in universities (see, for example, Boye, 2012). In their training workshops, Kearns and Subiño Sullivan (2011) provide traditional, five-paragraph essays as models as well as less traditional styles including The Great Moments, The Great and Not-So-Great Moments, The Story Retell, and The Metaphor (see Kearns for a full description). Korn (2012), in contrast, prefers to simply provide writers with an open-ended prompt, stating that, "this statement should be your philosophy, not that of some expert. It should be yours in form as well as in content" (p. 72). We maintain, however, that explicit instruction can be very helpful for novice writers and that the use of guidelines and models gives individual authors freedom to exercise agency in their choices.

A number of educators has also discussed the importance of writing the TP from a personal stance. The use of first-person pronouns by experienced writers has been the object of discussions in professional writing (e.g., Fløttum, Kinn, \& Dahl, 2006; Harwood, 2005; Martínez, 2005). This rhetorical marker is a "highly visible and measurable aspect of the identity constructing process" (Leedham, \& Fernandez-Parra, 2017, p. 67). Although the use of the first-person pronoun is sometimes frowned upon in professional writing (Hyland, 2002), empirical evidence suggests that this academic convention is subject to cultural and genre expectations (Leedham \& Fernandez-Parra, 2017; Stock \& Eik-Nes, 2016). Turning to research and available practical guides to writing a TP statement, authors often reiterate the importance of using first-person pronouns for this particular academic document (Boye, 2012; Chism, 1997-98; Korn, 2012). Boye (2012) argues that using the first-person pronoun "accommodates a variety of disciplines and is easiest to read" (p. 3) and, perhaps more important, speaks to one's personal and ongoing teaching style. These studies, however, have focused narrowly on first-person pronouns $I$ and we and have not considered other linguistic features, such as possessive adjectives. Given that those who write TPs are also socialized into academic writing conventions, we believe there is value in examining the practices of in-service teachers in relation to the use of pronouns and possessive adjectives.

\section{The Present Study}

To date, publications that discuss the topics of TPs and offer guidance on how to write a TP in the context of higher education abound; however, there is a paucity of such studies in the context of language education, specifically, within the field of TESL. Given the importance of this document for securing 
faculty positions that include teaching responsibilities (Sheffield, 2013) and the fact that few studies have examined this genre in the L2 context, the present research aims at addressing this gap by conducting a detailed analysis of in-service EAL teachers' written TPs to uncover the topics that are recurrent in TPs written for employment purposes. This analysis will help determine if there are commonalities and/or differences between TPs written by EAL professionals and by candidates searching for academic positions in higher education contexts. The present study will also examine nuances between TPs that are judged more favorably by TESL specialists and EAL program directors as compared with TPs ranked less so. This exploratory dimension of the study has not been examined in previous work. Finally, to determine if a personal narrative is viewed positively, the study will explore the use of pronouns and possessive adjectives in TPs. We specifically targeted in-service teachers' TPs given the fact that these professionals had a written TP that had been submitted in the process of securing an EAL teaching job. The specific research questions $(\mathrm{RQ})$ are the following:

Research Question 1: What are the dominant topics in TPs written by inservice language teachers?

Research Question 2: In a comparison across the Strongest, Strong, and Least Strong TPs:

a. What are the dominant topics in each group?

b. What are the opening and closing topics?

Research Question 3: What are the preferred pronouns and possessive adjectives of the Strongest, Strong, and Least Strong TPs?

\section{Method}

This section briefly discusses the methodology that was utilized to locate TPs, and the data analysis approach that was implemented.

\section{Data collection}

The data from this study come from a larger online survey-based study that explored the beliefs that in-service language teachers hold about TPs (see Payant, 2017 for more details). The survey included four major sections:

I: General Information,

II: Writing Practices,

III: Beliefs about TPs, and

IV: Demographic Data. 
Specifically, section I included a single true-false item: "I have a written TP." Those who responded affirmatively to this statement continued with section II, which explored in more depth their experiences leading up to their written TP, and those who answered negatively immediately advanced to section III, which focused exclusively on their beliefs. In the final section, participants were invited to share their e-mails if they were willing to share their TP. Of these, 27 teachers agreed to submit their TPs for subsequent analysis. The teachers were primarily women $(n=21$ or $77.8 \%)$ and represented four age groups: 14 were between 25 and 34 years old, five were between 35 and 44 , two were between 45 and 54, and six were 55 and above. At the time of the study, participants were teaching in an Intensive English Program (IEP) $(n=$ $14)$, in an ESL college/university setting $(n=7)$, in the K-12 context $(n=2)$, or in another type of setting $(n=4)$.

\section{Data Coding and Analysis}

To identify the dominant topics, each TP was imported into an Excel file. Each sentence was read carefully and coded for a primary topic $(N=432)$. Drawing on Kaplan et al. (2008), we began with the following possible categories: Goal for student learning, Enactment of goals, Assessment of goals, and Inclusive environments. However, upon closely examining our data, we realized that these a priori categories did not suffice. We then used an inductive approach, developing our own coding categories as they emerged from our data. We saw value in having narrow codes (leading to a large number of codes) to capture nuances in these TPs. Both researchers met and coded $20 \%$ of the TPs together. Following this initial stage, each researcher individually coded the remaining $80 \%$ of the TPs. The first author then compared the codes and identified any discrepancies. The inter-coder reliability was $88 \%$. The two researchers met and resolved the differences, through discussion, arriving at $100 \%$ agreement. In total, the analysis led to the identification of 24 primary topics (see Table 1). Given the exploratory nature of the study, we calculated the overall frequency for each of the 24 topics by dividing the total number of instances of a particular topic by the total number of topics, enabling us to respond to RQ1. We report percentages to show patterns of distribution in this exploratory study. 
Table 1

Coding Scheme

\begin{tabular}{|c|c|c|}
\hline Topics & Description & Example \\
\hline Teaching approach & $\begin{array}{l}\text { Presentation of methods and } \\
\text { approaches that guide and inform } \\
\text { practices }\end{array}$ & $\begin{array}{l}\text { I vary my presentation of material, } \\
\text { rather than relying solely on a } \\
\text { lecture, practice, homework routine. }\end{array}$ \\
\hline Teacher roles & $\begin{array}{l}\text { Presentation of roles, often in the } \\
\text { form of metaphors, to illustrate } \\
\text { responsibilities }\end{array}$ & $\begin{array}{l}\text { The teacher must be a motivator } \\
\text { and facilitator. }\end{array}$ \\
\hline Belief about teachers' role & $\begin{array}{l}\text { Presentation of beliefs about the } \\
\text { impact of individual teachers on } \\
\text { students and learning }\end{array}$ & $\begin{array}{l}\text { I believe in being the change I wish } \\
\text { to see in the world. }\end{array}$ \\
\hline Teaching beliefs & $\begin{array}{l}\text { Presentation of how teaching is } \\
\text { enacted; Description of the general } \\
\text { goals of pedagogy }\end{array}$ & $\begin{array}{l}\text { Teaching international students to } \\
\text { communicate effectively in English } \\
\text { is a challenging and rewarding } \\
\text { experience. }\end{array}$ \\
\hline Learning beliefs & $\begin{array}{l}\text { Presentation of classroom } \\
\text { dynamics/practices that facilitate } \\
\text { learning }\end{array}$ & $\begin{array}{l}\text { Creative, varied classroom } \\
\text { activities and assignments help } \\
\text { foster success. }\end{array}$ \\
\hline Belief about learners & $\begin{array}{l}\text { Presentation of beliefs about } \\
\text { learners' needs and wants }\end{array}$ & $\begin{array}{l}\text { Students expect technology in their } \\
\text { lives and can be motivated by its } \\
\text { use in the classroom. }\end{array}$ \\
\hline Goal for learners & $\begin{array}{l}\text { Discussion of outcomes/impact on } \\
\text { learners }\end{array}$ & $\begin{array}{l}\text { I want them to gain confidence } \\
\text { in themselves as users of the } \\
\text { language. }\end{array}$ \\
\hline Learner role & $\begin{array}{l}\text { Presentation of actual roles and } \\
\text { responsibilities of learners }\end{array}$ & $\begin{array}{l}\text { During full group discussions or } \\
\text { activities, various students, as well } \\
\text { as the teacher, might serve as } \\
\text { moderators. }\end{array}$ \\
\hline Teacher growth & $\begin{array}{l}\text { Presentation of actions and } \\
\text { resources that ensure ongoing } \\
\text { growth as a teacher }\end{array}$ & $\begin{array}{l}\text { Providing learning experiences for } \\
\text { students is providing a learning } \\
\text { experience for me. }\end{array}$ \\
\hline Scholar growth & $\begin{array}{l}\text { Presentation of actions and } \\
\text { resources that ensure ongoing } \\
\text { growth as a researcher }\end{array}$ & $\begin{array}{l}\text { Additionally, I will continue to } \\
\text { conduct action research with my } \\
\text { classes only in a more formal and } \\
\text { scientific way in an attempt to have } \\
\text { my results published. }\end{array}$ \\
\hline Example of practices & $\begin{array}{l}\text { Concrete examples of activities/ } \\
\text { exercises to support teaching and } \\
\text { learning }\end{array}$ & $\begin{array}{l}\text { I asked a student to take out her } \\
\text { smartphone (she had been texting } \\
\text { on it before class) and to download } \\
\text { the free Dictionary application and } \\
\text { find the definition for the class. }\end{array}$ \\
\hline Previous experience & $\begin{array}{l}\text { Presentation of teaching } \\
\text { experiences and/or experiences } \\
\text { beyond the act of teaching }\end{array}$ & $\begin{array}{l}\text { My professional background } \\
\text { is primarily in curriculum } \\
\text { development, educational } \\
\text { consulting, and instruction. }\end{array}$ \\
\hline
\end{tabular}




\begin{tabular}{|c|c|c|}
\hline Topics & Description & Example \\
\hline Source of knowledge & $\begin{array}{l}\text { Introduction of theories, research, } \\
\text { and people that inform teaching }\end{array}$ & $\begin{array}{l}\text { Knowledge of current pedagogical } \\
\text { practices and field-specific research } \\
\text { underpins the methods I use. }\end{array}$ \\
\hline Teacher identity & $\begin{array}{l}\text { Description of positions held that } \\
\text { shape teacher identities }\end{array}$ & $\begin{array}{l}\text { I am a member of a variety of } \\
\text { professional and non-professional } \\
\text { organizations. }\end{array}$ \\
\hline Belief about inclusiveness & $\begin{array}{l}\text { Presentation of actions to ensure } \\
\text { that each learner's individual needs } \\
\text { are met }\end{array}$ & $\begin{array}{l}\text { Pay special attention to each and } \\
\text { every student-say something } \\
\text { positive and encouraging to each } \\
\text { individual student. }\end{array}$ \\
\hline Belief about language & $\begin{array}{l}\text { Discussion of the role of English } \\
\text { in society }\end{array}$ & $\begin{array}{l}\text { I want students to know that } \\
\text { English is not just something which } \\
\text { must be learned for their futures, } \\
\text { but a powerful tool for them to use. }\end{array}$ \\
\hline Educational beliefs & $\begin{array}{l}\text { Presentation of beliefs about the } \\
\text { impact of education on society }\end{array}$ & $\begin{array}{l}\text { Above all, education should } \\
\text { empower students by giving them } \\
\text { the confidence that is needed to be } \\
\text { successful citizens. }\end{array}$ \\
\hline Professional goal & $\begin{array}{l}\text { Discussion of future goals and } \\
\text { aspirations as an educator }\end{array}$ & $\begin{array}{l}\text { I would be glad to teach basic } \\
\text { English courses, particularly in } \\
\text { reading, vocabulary, and writing. }\end{array}$ \\
\hline Quote & Inclusion of quotes and citations & $\begin{array}{l}\text { "For the things we have to learn } \\
\text { before we can do them, we learn by } \\
\text { doing them." }\end{array}$ \\
\hline Reflective practices & $\begin{array}{l}\text { Presentation of evidence of } \\
\text { reflective activities }\end{array}$ & $\begin{array}{l}\text { Personally, I keep a "Teaching } \\
\text { Journal" that records my thoughts } \\
\text { on each lesson in order to track the } \\
\text { effectiveness of my teaching. }\end{array}$ \\
\hline Personal background & $\begin{array}{l}\text { Presentation of previous jobs and } \\
\text { personal travels that shaped who } \\
\text { they are today }\end{array}$ & $\begin{array}{l}\text { My international experiences have } \\
\text { changed how I see the world. }\end{array}$ \\
\hline Academic preparation & $\begin{array}{l}\text { Presentation of program-specific } \\
\text { knowledge }\end{array}$ & $\begin{array}{l}\text { And while I learned various } \\
\text { teaching philosophies while } \\
\text { studying in X's MA English } \\
\text { program, ... }\end{array}$ \\
\hline Trajectory towards profession & $\begin{array}{l}\text { Presentation of experiences } \\
\text { that motivated them to become } \\
\text { teachers }\end{array}$ & $\begin{array}{l}\text { Furthermore, I truly found my niche } \\
\text { in teaching when I took on a part- } \\
\text { time job tutoring adult ELLs at the } \\
\text { University of } X \text {. }\end{array}$ \\
\hline
\end{tabular}

Note. ELL = English language learner; $\mathrm{MA}=$ Master degree.

The goal of the second RQ was to compare the traits of TPs that were judged more positively than others. In a first instance, the two researchers differentiated the stronger TPs from the less strong TPs. Our holistic evaluation of these was informed by pre-existing literature (e.g., $\mathrm{O}^{\prime} \mathrm{Neal}$ et al., 2007), by our experiences researching the supporting genre, by our extensive 
experiences teaching and evaluating TPs written by pre-service teachers, and by our experiences as search committee members evaluating TPs submitted for teaching positions. To provide a sense of each researcher's understanding of effective TPs, we provide, in Table 2, guidelines shared with their preservice teachers to assist them in the process of writing their first TPs and prepare them to eventually apply for teaching positions in ESL programs.

Table 2

Guiding Instructions to Draft a TP

Author 1: Payant

The statement of teaching philosophy presents your core beliefs regarding $L 2$ teaching and learning. It is . . . a personal essay that uses rich illustrations from your own experience (teaching, observations, foreign language learning experiences, conversations with students and mentor teachers, etc.) and ideas from the published literature to explain your personal convictions (your position) about teaching ESL/EFL. While this is to be a personal essay, you can cite scholars and educators who have influenced your thinking.
Author 2: Hirano

These are some of the topics you may want to include (adapted from Swales \& Feak, 2011): Your thoughts about how students learn; Your thoughts about how instruction can best help student learning; Your learning goals for students; Your thoughts about how your teaching might further improve; Your thoughts about how students (and instructors) might best be evaluated; Your thoughts about how teaching/learning language may be different from teaching/learning other types of content.

Note. $\mathrm{TP}=$ teaching philosophy; $\mathrm{L} 2$ = second language; $\mathrm{ESL}=$ English as a second language; $\mathrm{EFL}=$ English as a foreign language.

The two researchers identified 17 TPs that were effective in communicating convictions about teaching, leading to the initial distinction between the stronger and least strong TPs. Note that we avoided the term weak or weaker for this group as these were written by in-service teachers and had been submitted to employers as part of their application packet.

To capture more subtle nuances between the 17 stronger TPs, we subsequently contacted two directors of English programs to obtain their evaluation of the TPs. At the time of the study, the directors worked at two Intensive English Programs and required a TP as a supporting document for the job application process. They were instructed to read the TPs as though they were part of application packets and to identify the strongest 12 TPs from the pool of 17 previously identified as being stronger. The two directors converged on nine TPs, which were labeled Strongest. The analysis led to the following final ranking: Strongest: $n=9$; Strong: $n=8$; and Least Strong: $n=10$. Following this stage, we calculated the percentages of the most frequent topics for the three groups and also identified the initial and final topics from each TP. This final dimension of the analysis enabled us to paint a portrait of the opening and closing sections across the three groups.

In addition to the topic-based analysis, our third RQ examined linguistic features. We tabulated all instances of the target pronouns and possessive adjectives, which were subsequently divided into three groups, namely, self 
(i.e., I, me, my), other (i.e., they, them, their), and inclusive (we, us, our), using the vocabprofile option in the Compleat Lexical Tutor (Cobb, 2017).

\section{Findings}

Topic Analysis

To respond to the first $R Q$, we examined the most common topics for the entire data set, which are displayed in Figure 1. The percentages were calculated by dividing the raw frequency of each topic by the total number of topics. The two dominant topics were Teacher roles (18.8\%) and Teaching approach $(15.3 \%)$.

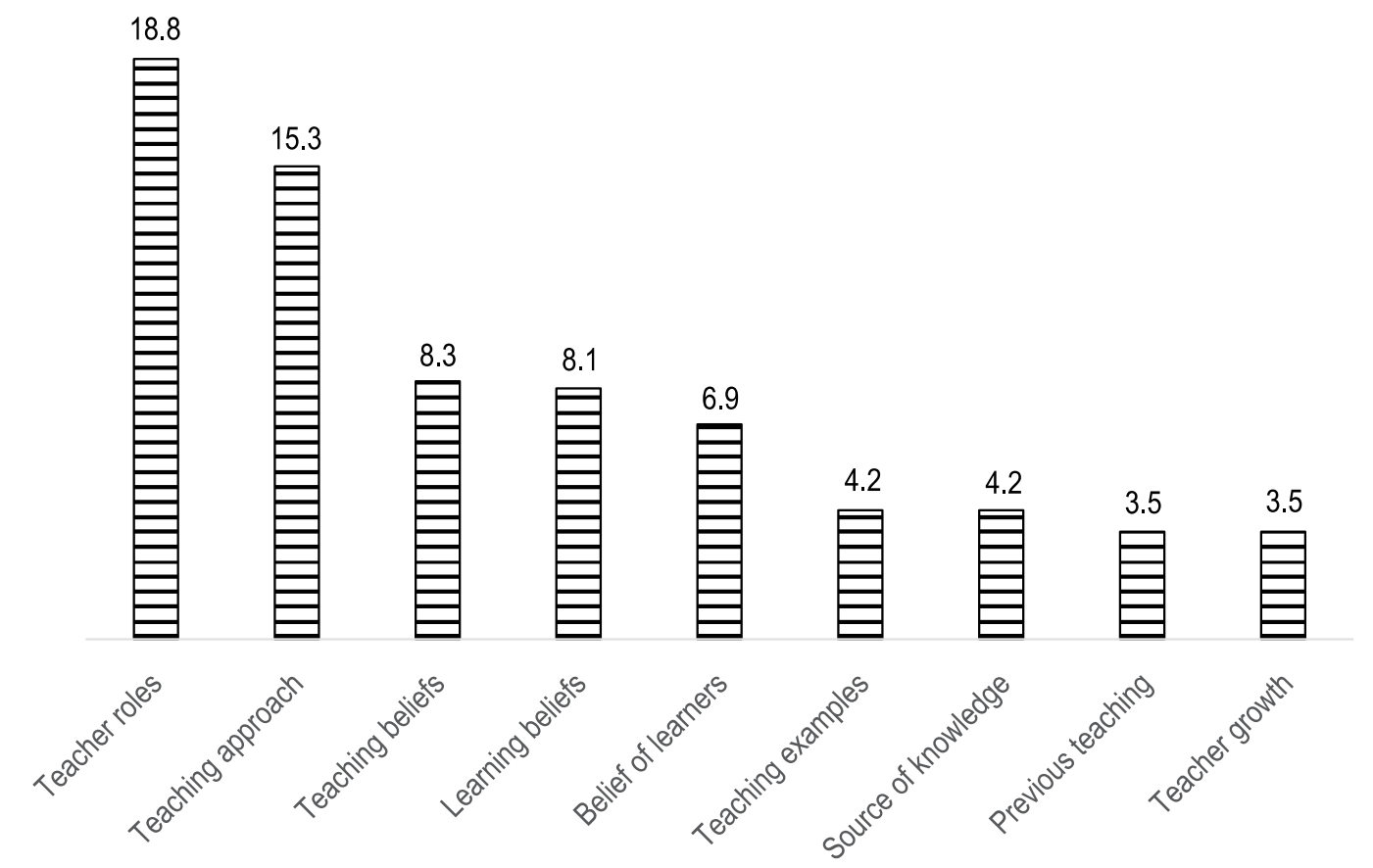

Figure 1: Dominant topics that comprise the teaching philosophies.

The next two most prominent topics were Teaching beliefs (8.3\%) and Learning beliefs $(8.1 \%)$, followed by Beliefs about learners (6.9\%). Teaching examples and Sources of knowledge represented $4.2 \%$ each. These nine topics accounted for $73 \%$ of the topics found in these TPs.

To respond to the second $R Q$, the TPs were organized into three groups according to a holistic rating: Strongest TPs $(n=9)$, Strong $(n=8)$, and Least Strong $(n=10)$. To calculate the percentages, each topic was divided by the total number of topics within each group (see Figure 2). Several topics were seldom represented in the TPs and, for this reason, we present only the findings for topics that were included at least $8 \%$ of the time by at least one group. The Strongest TPs focused extensively on Teaching approach (23.5\%) 
compared with only $16.5 \%$ for the Strong TPs and only $13.8 \%$ for the Least Strong TPs. The dominant topic in the Strong and the Least Strong TPs was Teacher roles, with $19 \%$ and $16.2 \%$, respectively. While the Strongest TPs also included Teacher roles (12.6\%), there appeared to be a good balance between Teacher roles (12.6\%), Learning beliefs (11.6\%), Teaching beliefs $(10.6 \%)$, and Teaching examples (8.9\%).

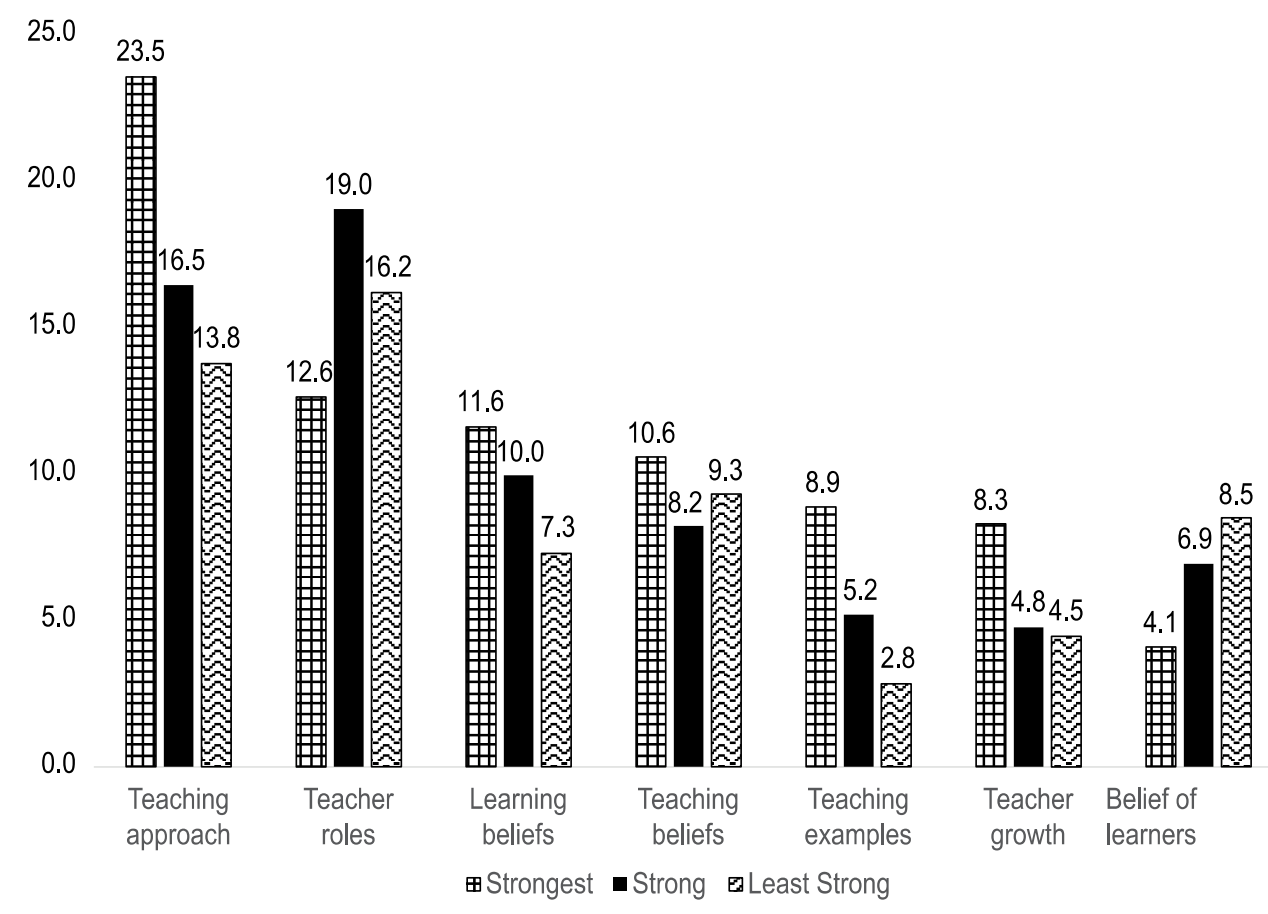

Figure 2: Dominant topics found across the three groups.

Next, we examined the first and last five topics for the three groups. The most common topics to include at the start of the Strongest TPs were Learning beliefs (17.8\%), followed by Teacher roles $(13.3 \%)$, Teaching approach $(11.1 \%)$, and Teacher growth $(11.1 \%)$, as seen in Figure 3. The most common topics to include at the start of the Strong TPs were Teacher roles $(25.0 \%)$, followed by Learning beliefs (15.0\%), and Teaching beliefs (12.5\%). This group of writers seldom discussed Teaching approach (2.5\%). Finally, in the Least Strong TPs, there was some overlap with the other groups in terms of preferred topics, but their percentages were quite different from the Strongest TPs. Specifically, a discussion of Teacher roles was the highest $(20.0 \%)$, and this was followed by Teaching beliefs $(9.1 \%)$ and Teaching approach $(7.3 \%)$. The largest discrepancies for this group from the other two were identified for Teacher growth, discussed only $1.8 \%$ of the time, and Learning beliefs (5.5\%). 


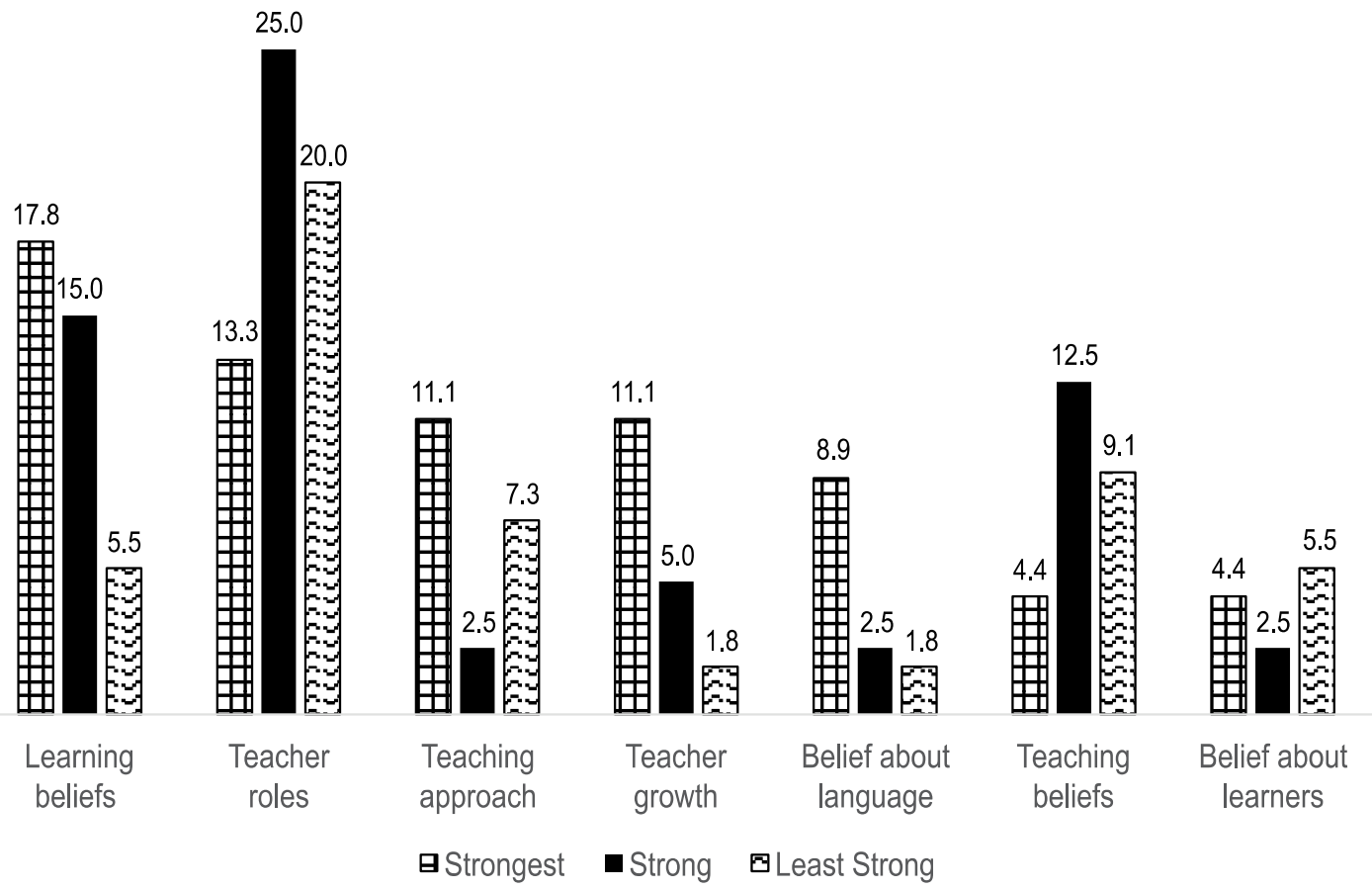

Figure 3: Starting topics across the three groups.

The analysis of the closing topics also yielded some important differences, as depicted in Figure 4. In the Strongest and Strong TPs, while teachers revisited their roles (17.8\% and $17.5 \%$, respectively), a major focus for closing was on Teacher growth (17.8\% and $17.5 \%$, respectively). However, only in the Strongest TPs were Teaching beliefs (17.8\%) discussed. In comparison, the Least Strong TPs appeared to continue to focus extensively on Teacher roles $(34.0 \%)$ and Teaching approach $(18.0 \%)$.

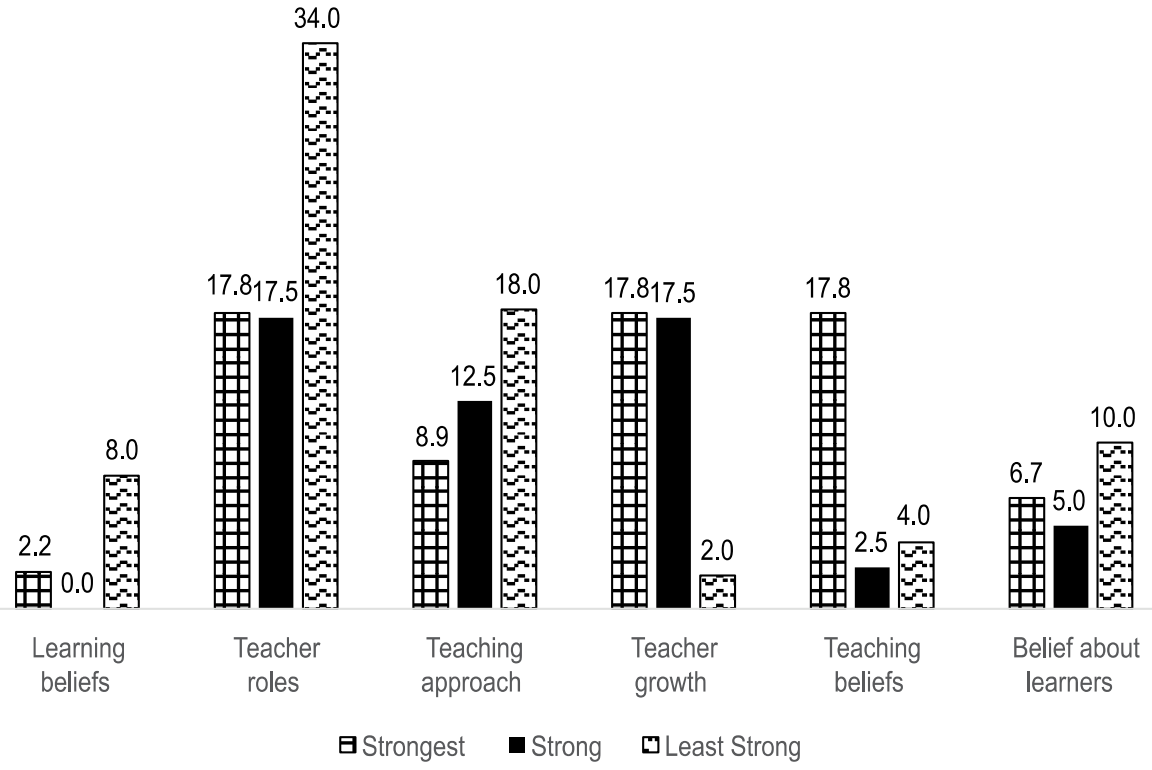

Figure 4: Closing topics across the three groups. 


\section{Features: A Look at Lexical Variation}

Table 3 provides descriptive statistics for the TPs, subdivided by group. The average number of words and word types tends to be highest for the Strongest TPs, namely, $M=642.3$ and $M=295.1$, respectively. However, the standard deviation (SD) is quite large given that one particular TP was 1,330 words long. The Least Strong TPs, in contrast, tended to be much shorter and had fewer word types, namely, $M=432.8$ and $M=180.5$, respectively.

Table 3

Descriptive Statistics of Teaching Philosophies by Group

\begin{tabular}{lllllll}
\hline & \multicolumn{2}{c}{ Strongest } & \multicolumn{2}{c}{ Strong } & \multicolumn{2}{c}{ Least Strong } \\
& \# of words & Word types & \# of words & Word types & \# of words & Word types \\
$M$ & 642.3 & 295.1 & 612.4 & 277.9 & 432.8 & 202.2 \\
SD & 285.8 & 85.6 & 213.0 & 82.4 & 180.5 & 67.4 \\
\hline
\end{tabular}

Note. $M=$ mean; $S D=$ standard deviation.

In addition to identifying general trends in length and lexical diversity, we closely examined the use of personal pronouns and possessive adjectives by the three groups. As discussed in the methodology, we organized these according to three orientations, namely, self (i.e., I, me, my), other (i.e., their, them, their), and inclusive (i.e., we, us, our). Table 4 provides the raw count and percentages (in relation to total number of words) for each pronoun and possessive adjectives as well as their combined numbers for each orientation.

Table 4

Distribution of Personal Pronouns and Possessive Adjectives

\begin{tabular}{lllllll}
\hline & & Strongest & \multicolumn{3}{c}{ Strong } & Least Strong \\
& Raw & $\%$ & Raw & $\%$ & Raw & $\%$ \\
I & 163 & 2.69 & 116 & 2.31 & 90 & 2.17 \\
Me & 72 & 0.45 & 14 & 0.28 & 9 & 0.22 \\
My & 117 & 1.93 & 87 & 1.73 & 57 & 1.38 \\
\hline Total & 352 & 5.07 & 217 & 4.32 & 156 & 3.77 \\
\hline We & 13 & 0.21 & 7 & 0.14 & 1 & 0.02 \\
Us & 1 & 0.02 & 2 & 0.04 & 1 & 0.02 \\
Our & 9 & 0.15 & 5 & 0.10 & 6 & 0.14 \\
\hline Total & 23 & 0.38 & 14 & 0.28 & 8 & 0.19 \\
\hline They & 31 & 0.68 & 41 & 0.82 & 39 & 0.94 \\
Them & 27 & 0.51 & 22 & 0.44 & 8 & 0.19 \\
Their & 41 & 1.19 & 65 & 1.29 & 51 & 1.23 \\
\hline Total & 99 & 2.38 & 128 & 2.55 & 98 & 2.37 \\
\hline
\end{tabular}


The self-oriented personal pronouns account for $5.07 \%$ of the words in the Strongest TPs, followed by $4.32 \%$ and $3.77 \%$ in the Strong and Least Strong TPs, respectively. The inclusive pronouns, albeit not frequent, were identified with greater frequency in the Strongest TPs $(0.38 \%)$ compared with only $0.19 \%$ in the Least Strong TPs. Finally, the distribution for the other-oriented is quite similar across the three groups.

\section{Discussion}

The goal of the present study was to identify dominant topics found in EAL teachers' TPs and to capture the features of the Strongest and Least Strong TPs, from the perspective of EAL specialists. Our detailed sentence-based analysis showed that a majority of TPs include Teaching approaches, Teacher roles, Teaching beliefs, and Learning beliefs. We found that the Strongest TPs differed from the Least Strong TPs particularly in the discussion of Teaching approaches, Teacher growth, and illustration of their practices with Teaching examples. Overall, we found that the Strongest TPs tended to be more consistent in that the six dominant topics (i.e., Teaching approach, Teacher roles, Learning beliefs, Teaching beliefs, Teaching examples, and Teacher growth) accounted for $80 \%$ of the topics discussed in the TPs. Conversely, these same six topics accounted for $65.8 \%$ of the content for the Strong TPs, and only $54 \%$ of the Least Strong TPs. In other words, stronger TPs tend to have a narrower focus.

In the context of higher education, it is not unusual for Teaching and Learning Centers on university campuses to provide workshops and guidelines for how to write a TP to help individuals searching for academic positions (Boye, 2012; Coppola, 2002; Kearns \& Subiño Sullivan, 2008). Our study, focusing specifically on individuals from the field of TESL, found some commonalities in terms of TPs' primary topics with previous research. An important way in which our findings and previous research align pertains to the discussion of Teaching approaches (e.g., Teaching methods and evaluations in Schönwetter et al. [2002] and Enactment of Goals in Kaplan et al. [2008]). Clearly, this dimension is of utmost importance if a TP is to convey to the reader what the teacher does in the classroom. As Korn (2012) claims, "what you actually do as a teacher is the ultimate challenge to your philosophy" (p. 77).

Another overlap concerned beliefs about teaching and learning. In higher education contexts, Schönwetter et al. (2002) argue that a strong TP will present the writers' definition or beliefs about teaching and learning and support this with knowledge of the literature. In our sample, Beliefs about teaching and Beliefs about learning were, indeed, discussed, but they were not grounded in the literature. In fact, the use of references to define teaching and learning, or otherwise, was mostly absent from the data set. Thus, we posit that, for EAL teachers, the discussion of beliefs about teaching and 
learning can be done without necessarily making explicit reference to scholarly references to establish credibility but authors must strive to demonstrate their knowledge through practical discussions and use of relevant terminology. Finally, across the two contexts, we found that TPs accounted for learners from diverse backgrounds. Kaplan et al. (2008) propose several guiding questions to promote this type of reflection. Schönwetter et al. (2002) are less explicit but still include language that requires a discussion of learners' characteristics and how these interact with the learning environment. In TESL, Beliefs about learners was the fifth most frequent topic, which suggests that EAL teachers are aware of the importance of discussing their learners who come from different cultures. As such, it is critical that we engage in ongoing reflections about learners' backgrounds and needs and also explore ways to illustrate this cultural awareness in written TPs. In sum, the findings from the present study illustrate some common patterns that appear to transcend any particular discipline. Educators should be in a position to discuss Teaching approaches, Beliefs about teaching and about learner, and importantly, show how their pedagogical approaches take students' needs and experiences into consideration.

Despite these similarities, a number of differences emerged. Previous research from higher education contexts highlights the importance of including a discussion of goals and expectations for the relationship(s) between teachers and students. Besides the establishment of student learning goals (Kaplan et al., 2008), Schönwetter et al. (2002) focus on learner roles and learner characteristics. In our data set, however, we noted explicit and frequent discussion of what teachers can do to facilitate learning, namely, Teacher roles. This category was quite complex and encompassed numerous specific roles (e.g., affective partner, awareness raiser, coach, communicator, critical thinking promoter, culture imparter, curriculum builder, disciplinarian, empowerer, facilitator, feedback provider, flexible player, inclusiveness person, linguistic resource, guide, model, moral builder, motivator, socio-political resource, transmitter of knowledge, reflective practitioner, and researcher). The focus appears to be on the teacher, rather than on the learner. It was interesting to note, however, that this particular topic was less frequent in Strongest TPs. This finding suggests that a discussion of Teacher roles, while valuable, should be included judiciously.

There also appeared to be an important difference in how professional development and growth is addressed in EAL teachers' TPs. In the context of higher education, professional development is often related to scholarship and might not necessarily be discussed in a TP, at least according to Schönwetter et al. (2002) and Kaplan et al. (2008). In the present study, the authors discussed the importance of Teacher growth, especially in the Strongest TPs. In the field of TESL, with the reflective turn, we often encourage pre-service teachers to reflect on current and future practices (Richards \& Farrell, 2011). To facilitate these reflections, L2 teacher educators create various oppor- 
tunities for pre-service teachers to experience teaching and reflect on their emerging beliefs through micro-teaching, practicum courses, and internships (Crookes, 2003; Johnson \& Arshavskaya, 2011). It is, therefore, possible that TESL graduates are well positioned to engage in ongoing reflection that is grounded in actual teaching experience and can easily discuss ways to ensure professional growth by reflecting on these.

In the existing literature, a discussion of assessment practices is often included in TPs (Kaplan et al., 2008; Schönwetter et al., 2002). In the present dataset, however, this topic was neglected, a somewhat surprising finding. In all education settings, we believe that it is critical that pedagogical practices foster learning and that we can provide evidence of the relationship between what we do and student learning outcomes. This finding opens the door to further inquiry given the important function of assessment in education. We encourage future researchers to explore whether this topic is perceived as an asset to be included in TPs, especially in today's educational climate.

The present study, in addition to uncovering recurring topics in written TPs in the context of EAL teachers, investigated the organization of TPs. To the best of our knowledge, this is the first study that examined the organization of a TP. Before proceeding to the general trends, we wish to emphasize that we are not proposing that all TPs should follow this model as this could stifle creativity and perhaps lead to very generic and non-individualistic TPs. However, we have identified trends that are worth noting. The initial five topics among the Strongest TPs were Learning beliefs, Teacher roles, Teaching approach, Teacher growth, and Beliefs about language. These were not, however, the most frequent topics overall (see Figure 1). In other words, the most frequent topics might not, in fact, be necessarily the best starting topics. Based on the present analysis, Learning beliefs and Beliefs about language were more prominent at the start of the TP. This suggests that Teaching approaches, while important, might be best addressed later in the statement given that it might be more useful to help the reader first understand who the writer is and what their beliefs are before exploring their approaches. The analysis of the final five topics yielded more striking differences across the three groups. The topics of Teacher growth and of Teaching beliefs were more frequent in the Strongest TPs. In the Least Strong TPs, in contrast, Teacher growth was seldom considered. Rather, those TPs continued to discuss Teacher roles.

The TP serves to communicate a personal philosophy about teaching to a particular audience, in this case, potential future colleagues. In this sense, a TP is an important genre and to successfully communicate ideas, writers should have a good understanding of both the content (i.e., topics) and the ways to organize their ideas. Therefore, while we do not believe that there is a single way to organize the various topics, we do believe that the findings provide some insights in terms of how to begin and conclude a TP. As a result of this exploratory study, we believe that it may be important to expand this 
line of research and have more in-depth conversations with EAL teacher educators and search committee members to explore whether the TP is a genre that favors particular organizational strategies.

Finally, in terms of the use of pronouns, the literature on TP from higher education supports the use of first-person pronoun for this particular genre (Boye, 2102), and our data show that the Strongest TPs tended to use this particular strategy more frequently than the Least Strong TPs. Specifically, in the Strongest TPs, self-oriented personal pronouns were more frequent than in the other TPs. The following statements illustrate how writers of the Strongest TPs use this orientation to exemplify their beliefs and practices: "My approach to classroom teaching ...," "I incorporate ...," "In my classroom, ..." "My role is ...." and "I strive to be...." The use of the inclusive pronouns, likewise, happened more frequently in the Strongest TPs than in the Least Strong ones, although their frequencies were very small. Nevertheless, the inclusive pronoun can be a useful strategy for creating a sense of unity between the teacher and the students, as demonstrated in the following example: "As a class, we discussed which openings were most interesting, thought provoking, or effective and why." While previous studies and existing guidelines encourage the use of the first-person pronoun (Boye, 2012; Chism, 1997-98; Schönwetter et al., 2002), this is the first study to explore its actual use in TPs. We encourage writers to continue to use personal pronouns as it serves to turn the focus toward the author, which may help readers associate with the author more directly. We invite additional research on the impact of using the first-person and the third-person pronouns in TP statements.

Writing a TP is not an easy task, especially for less experienced teachers or PSTs, but is one that is valued by in-service teachers (Payant, 2017). To succinctly summarize our major findings and help future teachers conceptualize their TP, Table 5 shows the overall frequency of dominant topics and discusses patterns of the Strongest TPs. It also specifies the top four topics discussed at the start and at the end of the TPs (see Figures 2 and 3 for specific percentages). This chart, in conjunction with the variety of topics presented in Table 1, can be used to guide individuals who are in the process of writing or revising a TP for the job market. We want to reiterate, however, that additional topics should be considered, such as discussions of assessment practices and perhaps the role of technologies, which were not prominent in these data. 
Table 5

Summary of Main Findings

\begin{tabular}{lllll}
\hline & All TPs & \multicolumn{3}{l}{ Strongest TPs only } \\
\hline & Frequency & $\begin{array}{l}\text { Topic frequency } \\
\text { relative to others: }\end{array}$ & $\begin{array}{l}\text { Starting topics } \\
\text { (top 4) }\end{array}$ & $\begin{array}{l}\text { Closing topics } \\
\text { (top 4) }\end{array}$ \\
Teacher Roles & Very high & Lower & 2 & 1 \\
Teaching approach & Very high & Similar (very high) & 3 & 4 \\
Teaching beliefs & Medium & Similar (medium) & & 1 \\
Learning beliefs & Medium & Slightly higher & 1 & \\
Belief of learners & Medium & Slightly lower & & \\
Teaching examples & Low & Higher & & 1 \\
Teacher growth & Low & Higher & 3 & \\
\hline Note: TP = teaching philosophy. & &
\end{tabular}

\section{Conclusion}

To the best of our knowledge, this is the first study that conducted a detailed topic-based analysis of TP statements within the field of English-language teaching. Our analysis led to the identification of common topics between TPs written within the context of higher education and within TESL. Important, however, was the finding that there are dominant topics that comprise this supporting genre for this particular group of EAL teachers. As EAL professionals begin to write their TP for EAL positions in North American teaching contexts, it is important to, therefore, consider which topics are perhaps more important for working with language learners. In addition, the differences between stronger and less strong TPs can potentially be useful to novice writers as they embark on the process of writing their personal beliefs and practices about teaching and learning as well as to L2 teacher educators who often guide these writers in composing TPs for professional reasons.

Despite these valuable insights, some limitations should be acknowledged. First, the data set included a limited number of TPs that were produced by in-service teachers alone. Furthermore, we examined topics by drawing on the sentence as our unit of analysis. As mentioned by a reviewer, this may have been too restrictive. Future studies can build on the current topics to examine patterns across a larger data set with both pre-service, novice, and experienced teachers and draw on content analysis rather than sentence-level analysis. Another potential limitation for this study is that the authors of the TPs had received their training in English-speaking settings, were working in North American institutions, and only four participants had a first language other than English. Although the original questionnaire was shared in international forums and had respondents that represented a diverse group of teachers, those who agreed to share their TPs represented a relatively homogeneous group. Despite these limitations, the study opens an avenue for 
future work with EAL teachers from additional cultural communities. This type of research would help further demystify the nature of this supporting genre for EAL teachers.

The goal of this research was to uncover the genre of the TP that is written for instrumental purposes. However, in line with more reflective approaches to teacher development, we wish to reiterate that the TP is a document that should not be conceptualized uniquely as a tool for procuring teaching positions. Rather, we believe the TP plays a reflective function that aids professional development and growth. We hope that L2 teacher educators will continue to invite their pre-service teachers to reflect extensively and creatively on how and what to teach.

\section{The Authors}

Dr. Caroline Payant is an assistant professor at the Université du Québec à Montréal. Her research examines the intersection between additional language development and task-based learning with adult learners of English, French, and Spanish in classroom and experimental settings, and second language (L2) teacher training. Her work can be found in the Canadian Modern Language Review, Foreign Language Annals, International Journal of Bilingual Education and Bilingualism, Studies in Second Language Acquisition, and TESOL Journal.

Dr. Eliana Hirano is an associate professor of Teacher Education and the Coordinator of the Minor in Teaching English as a Foreign Language at Berry College. Her research explores the intersection between identity and language learning, academic literacies in higher education with a focus on refugee-background college students, and L2 teacher education. Her work can be found in journals such as English for Specific Purposes, ELT Journal, and Journal of Second Language Writing.

\section{Acknowledgements}

We wish to thank the teachers who shared their teaching philosophy statements. We also wish to thank the anonymous reviewers for their constructive comments and feedback and the support from the team at TESL Canada Journal.

\section{References}

Avraamidou, L. (2015). Reconceptualizing elementary teacher preparation: A case for informal science education. International Journal of Science Education, 37(1), 108-135. doi:10.1080/0950 0693.2014 .969358

Boye, A. (2012, July). Writing your teaching philosophy. Teaching, Learning, and Professional Development Center. Texas Tech University, 1-7. Retrieved from https://www.depts.ttu.edu/tlpdc/ Resources/Teaching_resources/TLPDC_teaching_resources/Documents/WritingYourTeachingPhilosophywhitepaper.pdf

Chism, N. V. N. (1997-98). Developing a philosophy of teaching statement. Essays on Teaching Excellence: Toward the Best in the Academy, 9(3). Retrieved from http://ucat.osu.edu/wordpress/ assets/V9-N3-Chism.pdf 
Cobb, T. VocabProfile Home [computer program]. Accessed June 15, 2017 at https://www.lextutor.ca/vp/

Coppola, B. P. (2002). Writing a statement of teaching philosophy: Fashioning a framework for your classroom. Journal of College Science Teaching, 31(7), 448-453. Retrieved from http://emp. byui.edu/firestonel/bio405/readings/Teaching\%20Philosophy.pdf

Crookes, G. (2003). A practicum in TESOL: Professional development through teaching practice. Cambridge: Cambridge University Press.

Donnelly, R. (2009). Supporting teacher education through a combined model of philosophical, collaborative, and experiential learning. Journal of the Scholarship of Teaching and Learning, 9(1), 35-63. Retrieved from https://scholarworks.iu.edu/journals/index.php/josotl/article/ view/1713

Fløttum, K., Kinn, T., \& Dahl, T. (2006). “We now report on" versus "let us now see how": Author roles and interaction with readers in research articles. In K. Hyland, \& M. Bondi (Eds.), Academic discourse across disciplines. Bern: Peter Lang.

Freeman, D., \& Johnson, K. E. (1998). Reconceptualizing the knowledge-base of language teacher education. TESOL Quarterly, 32(3), 397-417. doi:10.2307/3588114

Goodyear, G. E., \& Allchin, D. (1998). Statements of teaching philosophy. In M. Kaplan (Ed.), To improve the academy (pp. 103-122). Stillwater, OK: New Forums Press.

Harwood, N. (2005). "Nowhere has anyone attempted ... In this article I aim to do just that". A corpus-based study of self-promotional "I" and "we" in academic writing across four disciplines. Journal of Pragmatics, 37(8), https://doi.org/10.1016/j.pragma.2005.01.012

Hyland, K. (2002). Options of identity in academic writing. ELT Journal, 56(4), 351-358. https:// doi.org/10.1093/elt/56.4.351

Hyland, K. (2004). Genre and second language writing. Ann Arbor: The University of Michigan Press.

Johnson, K. E. (2009). Second language teacher education: A sociocultural perspective. New York: Routledge.

Johnson, K. E., \& Arshavskaya, E. (2011). Strategic mediation in learning to teach: Reconceptualizing the microteaching simulation in an MA TESL methodology course. In K. E. Johnson \& P. R. Golombek (Eds.), Research on second language teacher education: A sociocultural perspective on professional development (pp. 169-185). New York: Routledge.

Johnston, B., \& Goettsch, K. (2000). In search of the knowledge base of language teaching: Explanations by experienced teachers. The Canadian Modern Language Review/La revue canadienne des langues vivantes, 56(3), 437-468. doi:http://dx.doi.org/10.3138/cmlr.56.3.437

Kaplan, M., Meizlish, D. S., O’Neal, C., \& Wright, M. C. (2008). A research-based rubric for developing statements of teaching philosophy. In D. R. Robertson \& L. B Nilson (Eds), To improve the academy: Resources for faculty, instructional, and organizational development (pp. 242-262). San Francisco, CA: Jossey-Bass.

Kearns, K. D., \& Subiño Sullivan, C. S. (2011). Resources and practices to help graduate students and postdoctoral fellows write statements of teaching philosophy. Advances in Physiology Education, 35(2), 136-145. doi:10.1152/advan.00123.2010

Korn, J. (2012). Writing and developing your philosophy of teaching. In W. Buskits \& V. A. Benassi (Eds.), Effective college and university teaching: Strategies and tactics for the new professoriate (pp. 71-80). Thousand Oaks, CA: Sage. 
Lee, J., Murphy, J., \& Baker, A. (2016) “Teachers are not empty vessels”: A reception study of Freeman and Johnson's (1998) reconceptualization of the knowledge base of second language teacher education. TESL Canada Journal, 33(1), 1-21. https://doi.org/10.18806/tesl.v33i1.1224

Leedham, M., \& Fernandez-Parra, M. (2017). Recounting and reflecting: The use of first person pronouns in Chinese, Greek and British students' assignments in engineering. Journal of English for Academic Purposes, 26, 66-77. http://doi.org/10.1016/j.jeap.2017.02.001

Martínez, I. A. (2005). Native and non-native writers' use of first person pronouns in the different sections of biology research articles in English. Journal of Second Language Writing, 14(3), 174-190. https://doi.org/10.1016/j.jslw.2005.06.001

Meizlish, D., \& Kaplan, M. (2008). Valuing and evaluating teaching in academic hiring: A multidisciplinary, cross-institutional study. Journal of Higher Education, 79, 489-512. doi:10.1353/ jhe.0.0017

O'Neal, C., Meizlish, D. \& Kaplan, M. (2007). Writing a statement of teaching philosophy for the academic job. Center for Research on Learning and Teaching Occasional Papers, 23, 1-8. Retrieved from https://www.sas.upenn.edu/ctl/grad/documents/UniversityofMichigan--TeachingPhilosophy_000.pdf

Payant, C. (2017). Teaching philosophy statements: In-service ESL teachers' practices and beliefs. TESOL Journal, 8(3), 636-656. https://doi.org/10.1002/tesj.290

Richards, J. C. \& Farrell, S. C. T. (2011). Practice teaching: A reflective approach. Cambridge: Cambridge University Press.

Sankey, L. L., \& Foster, D. D. (2012). A content analysis of teaching philosophy statements of award winning colleges of agriculture professors. Journal of Agricultural Education, 53(4), 124-140. doi:10.5032/jae.2012.04124

Schönwetter, D. J., Sokal, L., Freisen, M., \& Taylor, L. K. (2002). Teaching philosophies reconsidered: A conceptual model for the development and evaluation of TP statements. International Journal for Academic Development, 7(1), 83-97. doi:10.1080/13601440210156501

Sheffield, S. L. M. (2013). “Teaching experience preferred?" Preparing graduate students for teaching opportunities beyond North America. Collected Essays on Learning and Teaching, 6, 127-132. http://dx.doi.org/10.22329/celt.v6i0.3759

Schulman, L. (1987). Knowledge and teaching: Foundations of the New Reform. Harvard Educational Review, 57(1), 1-23. http://dx.doi.org/10.17763/haer.57.1.j463w79r56455411

Stock, I., \& Eik-Nes, N. L. (2016). Voice features in academic texts-A review of empirical studies. Journal of English for Academic Purposes, 24, 89-99. http://dx.doi.org/10.1016/j.jeap.2015.12.006

Swales, J. M., \& Feak, C. B. (2011). Navigating academia: Writing supporting genres. Michigan: The University of Michigan Press.

Vélez-Rendón, G. (2002). Second language teacher education: A review of the literature. Foreign Language Annals, 35(4), 457-467. https://doi.org/10.1111/j.1944-9720.2002.tb01884.x

Wright, T. (2010). Second language teacher education: Review of recent research on practice. Language Teaching, 43(3), 259-296. doi:10.1017/S0261444810000030 